(СМ. Ю. Олійник

Львівський національний медичний університет імені Данила Галицького

\title{
Значення тимчасового протезування для визначення постійної конструкції протезів у пацієнтів із вродженими незрощеннями верхньої губи та піднебіння після операційних втручань
}

Резюме. Пацієнти із вродженими незрощеннями губи та піднебіння (ВНГП) потребують довготривалої стоматологічної допомоги із залученням багатьох спеціалістів, а завершенням лікування вважається їх протетична реабілітація. Від адекватного опрацювання попередньої тимчасової конструкції значною мірою залежить передбачення та конструкція майбутнього зубощелепного протеза (захист вітальних зубів від хімічних і термічних подразників та вибір оптимального варіанта різцевого перекриття). Обстежено 21 хворого із ВНГП (10 чоловіків й 11 жінок), яким проведено комплексне протетичне лікування із застосуванням тимчасових, а згодом постійних ортопедичних конструкцій. Препарування зубів попередньо здійснювалося на моделях, у лабораторії проводили моделювання воскової тимчасової конструкції і перевід її у пластмасу, й лише після отримання тимчасового протеза починали препарування зубів у ротовій порожнині. При значних втраті зубів та невідповідності між розмірами верхньої та нижньої щелеп застосовували знімні конструкції протезів із подвійним зубним рядом, моделювали з урахуванням конструктивно-естетичної корекції та відтворення правильних оклюзійних співвідношень. А при "хибній» прогенії - знімні конструкції із подвійним зубним рядом і об’ємним моделюванням базису. Використання тимчасових конструкцій дає можливість уявити вигляд майбутнього протеза і від початку лікування забезпечити належну ортопедичну реабілітацію.

Ключові слова: вроджені незрощення губи і піднебіння, тимчасові ортопедичні конструкції.

\section{М. Ю. Олийнык}

Львовский национальный медицинский университет имени Данила Галицкого

\section{Значение временного протезирования для определения постоянной конструкции протезов у пациентов с врожденными несращениями верхней губы и неба после операционных вмешательств}

Резюме. Пациенты с врождёнными несращениями губы и нёба (ВНГН) требуют длительной стоматологической помощи с привлечением многих специалистов, а завершением лечения считается только их протетическая реабилитация. От адекватного выбора предыдущей временной конструкции в значительной мере зависят планирование и изготовление для них последующего постоянного зубочелюстного протеза (это защита витальных зубов от химических и термических раздражителей и выбор оптимального варианта резцового перекрытия). Обследовано 21 больного с ВНГН (10 мужчин и 11 женщин), которым проведено комплексное протетическое лечения с применением временных и постоянных ортопедических конструкций. Препарирование зубов предварительно осуществляли на моделях, затем в лаборатории проводили моделирование восковой временной конструкции и перевод ее в пластмассу, и только после получения временного протеза начинали препарирования зубов в полости рта. При недостаточном количестве зубов и значительном несоответствии между размерами верхней и нижней челюсти применяли съемные конструкции протезов с двойным зубным рядом, моделировали с учетом конструктивно-эстетической коррекции и воспроизведения правильных окклюзионных соотношений, а при «ложной» прогении - съемные конструкции с двойным зубным рядом и объемным моделированием базиса. Использование временных конструкций дает возможность пациенту с ВНГН представить вид будущего протеза и с самого начала лечения получать надлежащую ортопедическую реабилитацию.

Ключевые слова: врождённые несращения губы и нёба, временные ортопедические конструкции. 


\author{
M. Yu. Oliynyk \\ Danylo Halytskyi Lviv National Medical University
}

\title{
The value of the temporary prosthesis to determine the permanent dental construction in patients with congenital cleft lip and palate after surgical procedures
}

\begin{abstract}
Summary. Patients with congenital cleft lip and palate (CCLP) require long-term dental care with the involvement of many specialists, and the completion of the treatment can be considering only by their prosthetic rehabilitation. From the previous study, adequate temporary structure depends predictions and making them future prosthesis (protection is vital teeth from chemical and thermal stimuli and the choice of optimal variant incisive overlap). The study involved 21 patients with CCLP (10 men and 11 women) who underwent complex prosthetic treatment. Dissection of the teeth previously performed on the models, then conducted laboratory modeling wax temporary structures and the transfer it in plastic and only after the temporary prosthesis began preparing teeth in the mouth. If an insufficient number of teeth and a considerable disparity between the sizes of the upper and lower jaws used removable dentures with dental double row, modeled considering structural and aesthetic correction and correct occlusal relationships. In a large "false" progeny, orthopedic rehabilitation was making removable dentures with double row and three-dimensional basis modeling. The use of temporary dentures enables the patient to imagine the future prosthesis, as well as from the beginning of treatment receive appropriate orthopedic rehabilitation.
\end{abstract}

Key words: congenital cleft lip and palate, temporary prosthetic dentures.

Вступ. Серед усіх вроджених дефектів і деформацій щелепно-лицевої ділянки найбільш поширеними є вроджені незрощення верхньої губи та піднебіння (ВНГП), які посідають друге місце серед усіх вроджених вад новонароджених [1]. Пацієнти із вродженими незрощеннями верхньої губи та піднебіння (ВНГП), починаючи від народження і до досягнення 18-20-річного віку, потребують довготривалої стоматологічної реабілітації $[2,3]$. Після кваліфіковано наданої допомоги хірургом, ортодонтом, логопедом та іншими спеціалістами, у багатьох випадках завершенням лікування займається стоматолог-ортопед [4-6].

За наявності незначної невідповідності між розмірами верхньої та нижньої щелеп 3 діагностичною метою використовують пластинкові протези з подвійним зубним рядом та об’ємним моделюванням базису та тимчасові знімні покривні або незнімні конструкції також з об’ємним моделюванням штучних ясен $[3,7]$. При значній невідповідності - можливі комбінації незнімних і знімних варіантів конструкцій. Саме тому від попередньої тимчасової конструкції значною мірою залежить вибір конструкції майбутнього зубощелепного протеза.

Метою роботи був аналіз та опрацювання методики застосування часткових знімних покривних пластинкових протезів із подвійним зубним рядом та об'ємним моделюванням базису протеза у хворих на ВНГП з метою їх реабілітації на естетичному і функціональному рівнях.

Матеріали і методи. Обстежено 21 хворого 3 ВНГП, із них 10 - чоловіків і 11 жінок (співвідношення 1:1,1), яким проведено комплексне протетичне лікування із застосуванням тимчасових, а згодом постійних ортопедичних конструкцій. Суть формування тимчасової конструкції полягала у наступному: після вивчення моделей пацієнтів в артикуляторі й визначення виду тимчасової конструкції отримували відбитки альгінатною масою. Попереднє препарування зубів, що будуть покриті коронками, проводили на моделях. У лабораторії здійснювали моделювання воскової тимчасової конструкції і перевід їі у пластмасу. Лише після отримання тимчасового протеза починали препарування зубів у ротовій порожнині. Закінчивши препарування, внутрішню поверхню тимчасового протеза уточнювали нетоксичною пластмасою холодної полімеризації. Фіксували тимчасову конструкцію в ротовій порожнині з використанням кальційвмісного фіксаційного матеріалу. Усі цифрові дані були введені у програму для статистичного аналізу SPSS 13. Статистично 
значимим результат був визначений за умови, що $\mathrm{p}<0,05$.

Результати досліджень та ї обговорення. Стоматологи-ортопеди в процесі реабілітації хворих із ВНВГП часто стають перед дилемою щодо використання незнімних або знімних часткових конструкцій (протезів) [3]. Це можуть бути постійні знімні протези для пацієнтів, які відмовляються від повторного хірургічного втручання. Так, знімні конструкції особливо показані для пацієнтів із дефіцитом тканин, норицями з носової порожнини, дисфункцією м'якого піднебіння [7]. Крім того, передбачається, що протез може поліпшити психологічний стан пацієнтів і якість їх життя. Знімні конструкції вимагають меншого за обсягом протетичного втручання і можуть бути хорошою альтернативою для деяких пацієнтів із ВНГП, у яких є значна кількість відсутніх зубів [8]. При недостатній кількості зубів та значній невідповідності між розмірами верхньої та нижньої щелеп застосовуються знімні конструкції протезів із подвійним зубним рядом [4, 9]. Такі покривні пластинкові знімні протези з подвійним зубним рядом та об'ємним моделюванням базису, які виготовляються після закінчення ортодонтичного лікування, $є$ тимчасовими і використовуються до досягнення 18-20-річного віку, коли стає можливим постійне протезування [10, 11]. Моделювання тимчасової конструкції обов'язково здійснюється з урахуванням конструктивно-естетичної корекції, яка передбачає по- становку зубів з урахуванням їх анатомічної приналежності та центральної лінії, об’ємне моделювання вестибулярної частини альвеолярного відростка верхньої щелепи та закриття його дефекту для підтримки верхньої губи, що западає, відтворення оклюзійних співвідношень між штучними зубами протеза і нижнім зубним рядом у фронтальній і бічних ділянках [12].

Середній вік хворих, яким виготовлено знімні ортопедичні конструкції, складав $(20,50 \pm 0,90)$ року, і коливався від 13 до 32 років (табл. 1).У віковій групі 13-18 років знаходилося 7 пацієнтів (6 чоловіків і 1 жінка), середній вік - $(16,57 \pm 1,62)$ року ( $=0,0001)$, у віковій групі 19-24 років - 10 пацієнтів (4 чоловіки і 6 жінок), середній вік - $(20,65 \pm 0,37)$ року ( $\mathrm{p}=0,0001)$, 24 років і більше - 4 пацієнтів (жінок), середній вік - $(27,00 \pm 1,78)$ року $(\mathrm{p}=0,001)$. У процесі реабілітації пацієнтів виготовлено 7 знімних, незнімних конструкцій 13 і 1 комбінований протез (табл. 2). Усі знімні протези представлені частковими знімними пластинковими протезами, віковий інтервал пацієнтів - 18-32 років. Незнімні протези у даному дослідженні це виключно мостоподібні конструкції, 11 з яких шинуючі (віковий інтервал пацієнтів 17-25 років). Протягом тривалого часу курації кожен із тимчасових протезів періодично доводилося замінювати: усього виготовлено 56 конструкцій, у середньому припадало 2,7 конструкцій на пацієнта. Слід зазначити, що завершенням протетичної реабілітації ста-

Таблищя 1. Поділ хворих за видами незрощення і віковими групами за Ф. Я. Хорошилкиной $(\mathrm{n}=21)$

\begin{tabular}{|c|c|c|c|c|c|c|c|c|c|c|c|c|c|c|c|}
\hline \multirow{5}{*}{ Вікова група } & \multicolumn{9}{|c|}{ Вид незрощення } & \multirow{2}{*}{\multicolumn{4}{|c|}{ Усього }} & \multirow{5}{*}{ 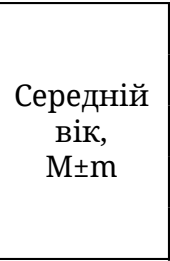 } & \multirow{5}{*}{$\mathrm{p}$} \\
\hline & \multirow{2}{*}{\multicolumn{3}{|c|}{$\frac{\text { правобічне }}{\text { стать }}$}} & \multirow{2}{*}{\multicolumn{3}{|c|}{$\begin{array}{c}\text { лівобічне } \\
\text { стать }\end{array}$}} & \multirow{2}{*}{\multicolumn{3}{|c|}{$\begin{array}{c}\text { двобічне } \\
\text { стать }\end{array}$}} & & & & & & \\
\hline & & & & & & & & & & & & ать & & & \\
\hline & \multirow{2}{*}{ чол. } & \multirow{2}{*}{ жін. } & \multirow{2}{*}{ разом } & \multirow{2}{*}{ чол. } & \multirow{2}{*}{ жін. } & \multirow{2}{*}{ разом } & \multirow{2}{*}{ чол. } & \multirow{2}{*}{ жін. } & \multirow{2}{*}{ разом } & \multirow{2}{*}{ чол. } & \multirow{2}{*}{ жін. } & \multicolumn{2}{|c|}{ разом } & & \\
\hline & & & & & & & & & & & & $\mathrm{n}$ & $\%$ & & \\
\hline $\begin{array}{l}\text { 13-18 років - } \\
\text { формування } \\
\text { постійного } \\
\text { прикусу }\end{array}$ & 2 & 1 & 3 & 2 & - & 2 & 2 & - & 2 & 6 & 1 & 7 & 33,3 & $16,57 \pm 0,62$ & 0,0001 \\
\hline $\begin{array}{l}\text { 19-24 років - } \\
\text { доформову- } \\
\text { вання } \\
\text { постійного } \\
\text { прикусу } \\
\end{array}$ & 2 & 1 & 3 & - & 3 & 3 & 2 & 1 & 3 & 4 & 6 & 10 & 47,6 & $20,65 \pm 0,37$ & 0,0001 \\
\hline $\begin{array}{l}24 \text { років і > - } \\
\text { сформований } \\
\text { постійний } \\
\text { прикус }\end{array}$ & - & - & - & & 2 & 2 & & 2 & 2 & - & 4 & 4 & 19,1 & $27,00 \pm 1,78$ & 0,001 \\
\hline Усього & 4 & 2 & 6 & 2 & 5 & 7 & 4 & 3 & 7 & 10 & 11 & 21 & 100 & $20,50 \pm 0,90$ & 0,0001 \\
\hline
\end{tabular}


Tаблиия 2. Види тимчасових ортопедичних конструкцій залежно від віку пацієнтів

\begin{tabular}{|c|c|c|c|c|}
\hline $\begin{array}{l}\text { № } \\
\text { 3/ח }\end{array}$ & $\begin{array}{c}\text { Вік } \\
\text { (роки) }\end{array}$ & $\begin{array}{l}\text { Вид тимчасового } \\
\text { протеза } \\
\end{array}$ & Конструкція протеза & $\begin{array}{l}\text { Кількість } \\
\text { протезів }\end{array}$ \\
\hline 1 & 13 & Комбінований & Повний знімний покривний протез із фіксацією на ковпачках & 2 \\
\hline 2 & 17 & Незнімний & Мостоподібна конструкція & 2 \\
\hline 3 & 17 & Незнімний & Мостоподібна шинуюча конструкція & 2 \\
\hline 4 & 17 & Незнімний & Мостоподібна шинуюча конструкція & 3 \\
\hline 5 & 17 & Незнімний & Мостоподібна шинуюча конструкція & 3 \\
\hline 6 & 17 & Незнімний & Мостоподібна шинуюча конструкція & 3 \\
\hline 7 & 18 & Знімний & Частковий знімний пластинковий протез & 3 \\
\hline 8 & 19 & Незнімний & Мостоподібна шинуюча конструкція & 3 \\
\hline 9 & 20 & Незнімний & Мостоподібна шинуюча конструкція & 3 \\
\hline 10 & 20 & Знімний & Частковий знімний пластинковий протез & 3 \\
\hline 11 & 20 & Знімний & Частковий знімний пластинковий протез & 3 \\
\hline 12 & 20 & Знімний & Частковий знімний пластинковий протез & 3 \\
\hline 13 & 20,5 & Знімний & Частковий знімний пластинковий протез & 3 \\
\hline 14 & 21 & Незнімний & Мостоподібна шинуюча конструкція & 3 \\
\hline 15 & 21 & Незнімний & Мостоподібна конструкція об’ємним моделюванням базису & 2 \\
\hline 16 & 22 & Незнімний & Мостоподібна шинуюча конструкція & 3 \\
\hline 17 & 23 & Незнімний & Мостоподібна шинуюча конструкція & 2 \\
\hline 18 & 24 & Незнімний & Мостоподібна шинуюча конструкція & 2 \\
\hline 19 & 25 & Незнімний & $\begin{array}{l}\text { Мостоподібна шинуюча конструкція з об’ємним } \\
\text { моделюванням базису }\end{array}$ & 3 \\
\hline 20 & 27 & Знімний & Частковий знімний пластинковий протез & 3 \\
\hline 21 & 32 & Знімний & Частковий знімний пластинковий протез & 2 \\
\hline
\end{tabular}

ло виготовлення 13 постійних ортопедичних конструкцій, які також, за необхідності, піддавалися коригуванню та заміні під час диспансерних оглядів пацієнтів. Одним із критеріїв застосування тимчасових конструкцій було створення максимально сприятливих умов для наступного вибору постійних протезів. При значній невідповідності розмірів верхньої та нижньої щелеп і так званій «хибній»

\section{Список літератури}

1. Вроджені синдроми у дітей, що супроводжуються незрощенням верхньої губи і піднебіння (епідеміологія, принципи та етапність лікування) / Л. В. Харьков, Л. М. Яковенко, А. В. Собко [та ін.] // Новини стоматології. - 2008. - № 1 (54). - С. 26-31.

2. Давлетшин Н. А. Реабилитация детей с врождённой расщелиной верхней губы и нёба в Республике Башкортостан : автореф. дисс. на соискание учён. степени д-ра мед. наук : спец. 14.00.21 «Стоматология" / Н. А. Давлетшин. - М., 2009. - 46 с. 3. Макєєв В. Ф. Клініка, діагностика та концептуальні основи у комплексному лікуванні дефектів та деформацій зубощелепної системи хворих 3 незрощеннями верхньої губи і піднебіння : авто- прогенії ортопедична реабілітація полягала у виготовленні знімної конструкції із подвійним зубним рядом і об'ємним моделюванням базису протеза $[13,14]$.

Висновки. Використання тимчасових конструкцій дає можливість лікарю та пацієнту 3 вродженим незрощенням губи і піднебіння уявити вигляд майбутнього протеза, а також із самого початку лікування отримувати належну ортопедичну реабілітацію.

реф. дис. на здобуття наук. ступеня д-ра мед. наук : спец. 14.01.22 «Стоматология» / В. Ф. Макєєв. - Львів, 2007. - 31 c.

4. Макєєв В. Ф. Загальні закономірності формування зубощелепних деформацій у хворих 3 незрощеннями верхньої щелепи та піднебіння до та після оперативного лікування / В. Ф. Макєєв // Вісник стоматології. - 2007. - № 6. - С. 50-59.

5. Хорошилкина Ф. Я. Ортодонтия. Дефекты зубов, зубных рядов, аномалии прикусу, морфофункциональные нарушения в челюстно-лицевой области и их комплексное лечение : учебн. пособ. / Ф. Я. Хорошилкина. - М. : Мед. информ. агенство, 2006. -544 c. 
6. Психотерапевтический подход при рождении ребенка с врождённой челюстно-лицевой патологией / Н. М. Гордиюк, Г. Г. Бойко, Л. А. Анисимова [и др.] // Вісник стоматології. - 2010. - № 2. - С. 9.

7. Raoul G. Specificity of prosthetic dental rehabilitation in cleft lip and palate sequels / G. Raoul, J. Ferri // Rev. Stomatol. Chir. Maxillofac. - 2007. - Vol. 108, № 4. P. 378-382.

8. Strickland F. Prosthodontic Rehabilitation of the Adult Cleft Palate Patient: A Case Report / F. Strickland, J. J. Psillakis, J. T. Grbic [et al.]//Columbia Dental Review.2004. - Vol. 9. - P. 1-9.

9. Майкл Уайз. Ошибки протезирования. Лечение пациентов с несостоятельностью реставраций зубного ряда / Майкл Уайз, Энтони Лори. - М. : «Азбука", 2007. - T. 2. - 231 с.

10. Mese A. Removable partial denture in a cleft lip and palate patient: a case report / A. Mese, E. Ozdemir // J. Korean Med. Sci. - 2008. - Vol 23, №. 5. - P. 924-927.

11. Moore D. Prosthetic dentistry and the unilateral cleft lip and palate patient. The last 30 years. A review of the prosthodontic literature in respect of treatment options / D. Moore, J. F. McCord // Eur. J. Prosthodont. Restor. Dent. - 2004. - Vol. 12, №. 2. - P. 70-74.

12. Макєєв В. Ф. Ортопедичні методи лікування хворих із вродженими незрощеннями верхньої губи та піднебіння / В. Ф. Макєєв, Т. Ю. Неміш, Г. В. Олійник . - Львів: Кварт, 2013. - 164 с.

13. Неспрядько В. П. Застосування тимчасових протезів у пацієнтів 3 м'язово-суглобовими функціональними розладами зубощелепно-лицевої ділянки в якості діагностично-лікувальних апаратів / В. П. Неспрядько, Ю. В. Клітинський, А. М. Прощенко // Науковий вісник НМУ ім. О. О. Богомольця. К., 2006. - № 2. - С. 98-100.

14. Олійник Г. В. Морфофункціональні особливості деформацій зубощелепної системи у хворих з вродженими незрощеннями верхньої губи і піднебіння та методи їх лікування в постійному прикусі : автореф. дис. на здобуття наук. ступеня канд. мед. наук : спец. 14.01.22 «Стоматология» / Г. В. Олійник. Львів, 2012. - 19 с.

Отримано 14.07.16 